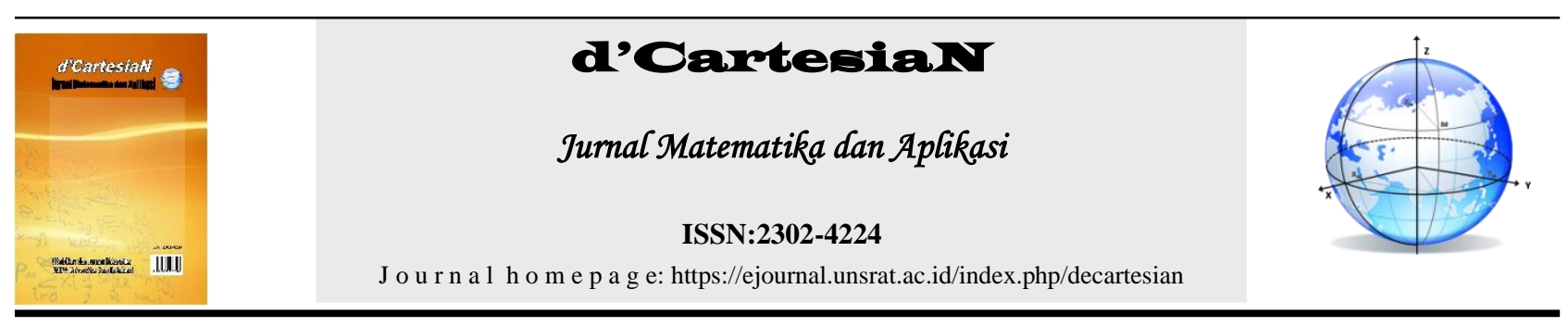

\title{
Model Optimasi Produksi Air Bersih PDAM Kabupaten Bolaang Mongondow Timur Menggunakan Metode Preemptive Goal Programming
}

\author{
Lita S. Kawulusan', Altien J. Rindengan', Yohanes A. R. Langi ${ }^{*}$ \\ ${ }^{1}$ Jurusan Matematika-Fakultas Matematika dan Ilmu Pengetahuan Alam-Universitas Sam Ratulangi Manado, Indonesia
}

${ }^{*}$ Corressponding author : yarlangi@gmail.com

\begin{abstract}
A B S T R A K
Air merupakan salah satu kebutuhan pokok makhluk hidup. Seiring dengan bertambahnya jumlah penduduk maka kebutuhan akan air bersih juga semakin bertambah, oleh sebab itu pemerintah mengelola sebuah perusahaan yaitu Perusahaan Daerah Air Minum (PDAM). Tujuan dari penelitian ini yaitu untuk menentukan hasil optimasi produksi air bersih dengan menggunakan metode preemptive goal programming pada PDAM Kabupaten Bolaang Mongondow Timur. Dengan menggunakan metode ini diperoleh jumlah produksi air bersih unit Modayag yaitu sebesar 16824,07 $\mathrm{m}^{3}$ dan unit Kotabunan sebesar 7624,92 $\mathrm{m}^{3}$ dengan jumlah pendapatan yang diperoleh unit Modayag sebesar Rp.120.291.468 dan unit Kotabunan sebesar Rp.55.192.006. Selain itu, tujuan memproduksi air bersih yang tidak melebihi kapasitas produksi dapat tercapai dimana unit Modayag tersisa sebesar 12983,93 $\mathrm{m}^{3}$ dan unit kotabunan tersisa 5335,08 $\mathrm{m}^{3}$ dari kapasitas produksi yang ditetapkan. Adapun fungsi tujuan memenuhi tingkat permintaan air bersih berdasarkan jenis pelanggan dapat terpenuhi dan tujuan untuk memproduksi air bersih yang melebihi produksi minimal air bersih terdapat satu variabel keputusan yaitu variabel keputusan jumlah produksi air bersih jenis pelanggan rumah sakit pemerintah unit Modayag yang memiliki nilai solusi optimal kurang dari produksi minimal air bersih, selain itu nilai variabel keputusan lainnya telah melebihi produksi minimal air bersih yang telah ditetapkan.
\end{abstract}

\section{INFO ARTIKEL :}

Diterima : 13 Juli 2020

Diterima setelah revisi : 28 Agustus 2020

Tersedia online : 2 Januari 2021

\section{Kata Kunci:}

Produksi air bersih, PDAM,

Preemptive Goal Programming, Optimasi.

\section{A B S T RA C T}

Water is one of the basic needs of living things. As the population increases, the need for clean water also increases, therefore the government manages a company, namely the Regional Drinking Water Company (PDAM). The purpose of this study is to determine the results of optimization of clean water production using the preemptive goal programming method at PDAM Bolaang Mongondow Timur Regency. By using this method, the amount of clean water production from Modayag units is $16824.07 \mathrm{~m} 3$ and Kotabunan units is $7624.92 \mathrm{~m}^{3}$ with the total revenue earned by Modayag units of IDR 120,291,468 and Kotabunan units of IDR 55,192. 006. In addition, the goal of producing clean water that does not exceed the production capacity can be achieved where the remaining Modayag units are $12983.93 \mathrm{~m}^{3}$ and the remaining municipal units are $5335.08 \mathrm{~m}^{\wedge} 3$ of the specified production capacity. The objective function of meeting the level of demand for clean water based on the type of customer can be fulfilled and the objective of producing clean water that exceeds the minimum production of clean water, there is one decision variable, namely the decision variable for the amount of clean water production for the type of customer at the Modayag unit government hospital which has an optimal solution value of less than minimum production of clean water, other than that the value of other decision variables has exceeded the predetermined minimum production of clean water.

\section{ARTICLE INFO :}

Received : 13 July 2020

Received after revision : 28 August 2020

Tersedia online : 2 January 2021

Keywords:

Clean water production, PDAM,

Preemptive Goal Programming, Optimation.

\section{PENDAHULUAN}

Air merupakan salah satu kebutuhan pokok makhluk hidup yang memiliki peranan penting dalam kehidupan. Seiring dengan bertambahnya jumlah penduduk maka kebutuhan akan air bersih juga semakin bertambah, oleh sebab itu pemerintah mengelola sebuah perusahaan milik daerah yaitu Perusahaan Daerah Air Minum (PDAM) yang bertugas untuk memberikan pelayanan kepada masyarakat dalam memenuhi kebutuhan air bersih untuk keperluan rumah tangga maupun industri.
Dalam memproduksi air bersih pihak PDAM dihadapkan dengan masalah dalam mengoptimalkan tujuan-tujuan yang ingin dicapai oleh perusahaan. Dimana tujuan-tujuan tersebut saling berkaitan dan bertentangan dengan tujuan-tujuan yang lainnya, oleh karena itu apabila tujuan-tujuan yang bertentangan salah satunya dioptimalkan maka akan mempengaruhi tujuan lainnya yang berakibat kerugian bagi pihak PDAM. Metode goal programming dalam hal ini berfungsi untuk menentukan jumlah air bersih yang harus diproduksi berdasarkan tujuan-tujuan yang ada 
sehingga akan diperoleh solusi yang optimal berdasarkan tujuan yang ingin dicapai oleh perusahaan.

Penelitian-penelitian yang dilakukan sebelumnya yaitu optimasi produksi air bersih pelanggan PT Air Manado dengan menggunakan metode goal programming [10]. Selain itu, [4] juga telah melaksanakan penelitian di Perusahaan Daerah Air Minum Kabupaten Minahasa Utara yang berjudul optimasi pendistribusian air dengan menggunakan metode least cost dan metode modified distribution. Selanjutnya, [5] melakukan penelitian yang berjudul optimasi pendistribusian raskin dengan menggunakan goal programming.

Penelitian ini bertujuan untuk menentukan hasil optimasi produksi air bersih dengan menggunakan metode preemptive goal programming dengan beberapa fungsi tujuan yang ingin dicapai yaitu memaksimalkan pendapatan penjualan air bersih, memenuhi permintaan air bersih, memproduksi air bersih yang tidak melebihi kapasitas produksi serta memproduksi air bersih yang melebihi produksi minimal air bersih. Dari beberapa fungsi tujuan tersebut kemudian diberikan prioritas yang berdasarkan keinginan dari pihak PDAM dengan prioritas yang pertama yaitu dapat memenuhi permintaan air bersih, prioritas kedua yaitu memaksimalkan pendapatan penjualan air bersih, prioritas ketiga yaitu memproduksi air bersih yang tidak melebihi kapasitas produksi dan prioritas yang keempat yaitu memproduksi air bersih yang melebihi produksi minimal air bersih.

\section{TINJAUAN PUSTAKA}

\subsection{Air Bersih}

Air bersih adalah air yang tidak berasa, tidak berwarna, dan tidak berbau yang di perlukan dalam kehidupan manusia, hewan, dan tumbuhan yang secara kimiawi mengandung hidrogen dan oksigen [7].

Air merupakan sarana utama untuk meningkatkan derajat kesehatan makhluk hidup terutama manusia, karena air merupakan salah satu media dari berbagai macam penularan penyakit terutama penyakit perut dan kulit yang banyak terjadi di Indonesia. Melalui penyediaan air bersih baik dari kualitas maupun kuantitas di suatu daerah, maka penyebaran penyakit seperti penyakit perut dan kulit diharapkan dapat ditekan seminimal mungkin [11].

\subsection{Perusahaan Daerah Air Minum (PDAM)}

Perusahaan Daerah Air Minum merupakan salah satu Badan Usaha Milik Daerah (BUMD) yang bergerak di bidang penyediaan air bersih untuk kebutuhan masyarakat [1].

\subsection{Model Trend Linear}

Trend adalah suatu gerakan (kecenderungan) naik atau turun dalam jangka panjang seperti diperoleh dari rata-rata perubahan dari waktu ke waktu. Rata-rata perubahan tersebut bisa bertambah dan bisa berkurang. Jika rata-rata perubahan bertambah disebut dengan trend positive. Trend mempunyai kecenderungan naik sebaliknya jika rata-rata perubahan berkurang disebut trend negative atau trend yang mempunyai kecenderungan menurun [8].

Trend linear adalah trend yang variabel $X$-nya (periode waktu) berpangkat paling tinggi satu. Trend linear memiliki bentuk persamaan garis lurus yaitu [8]:

$$
Y=a+b X
$$

Keterangan:

$Y=$ Data berkala atau nilai trend untuk periode tertentu

$X$ = Periode waktu (hari, minggu, bulan, tahun)

$a=$ Konstanta nilai $Y$ jika $X=0$

$b=$ Koefisien $X$ kemiringan garis trend (slope)

\subsection{Program Linear}

Program linear adalah suatu cara untuk menyelesaikan persoalan pengalokasian sumbersumber yang terbatas diantara beberapa aktivitas yang bersaing, dengan cara yang terbaik yang mungkin dilakukan [2].

Dalam membangun model dari formulasi suatu persoalan digunakan karateristik karaktersitik yang biasa digunakan dalam persoalan program linear, yaitu [2]:

1. Variabel Keputusan

Variabel keputusan adalah variabel yang menguraikan secara lengkap keputusan-keputusan yang akan dibuat.

2. Fungsi Tujuan

Fungsi tujuan merupakan fungsi dari variabel keputusan yang akan dimaksimumkan (untuk pendapatan atau keuntungan) atau diminimumkan (untuk ongkos).

3. Pembatas

Pembatas merupakan kendala yang dihadapi sehingga kita tidak bisa menentukan harga-harga variabel keputusan secara sembarang. Koefisien dari variabel keputusan pada pembatas disebut koefisien teknologis, sedangkan bilangan yang ada disisi kanan setiap pembatas disebut ruas kanan pembatas.

4. Pembatas Tanda

Pembatas tanda adalah pembatas yang menjelaskan apakah variabel keputusannya diasumsikan hanya berharga nonnegatif atau variabel keputusan tersebut boleh berharga positif, boleh juga negatif (tidak terbatas dalam tanda).

\subsection{Goal programming}

Goal programming adalah salah satu model matematis (empiris) yang dipakai sebagai dasar pengambilan keputusan. GP digunakan untuk menganalisis dan membuat solusi persoalan yang melibatkan banyak tujuan sehingga diperoleh alternatif pemecahan masalah yang optimal [9].

Dalam menggunakan model dari formulasi persoalan goal programming digunakan beberapa karakteristik yaitu [6]:

1. Variabel keputusan/ Decision variables $\left(x_{j}\right)$ : seperangkat variabel yang tak diketahui yang akan dicari nilai-nilainya.

2. Right Hand Side values (RHS): nilai yang biasanya menunjukkan ketersediaan sumber daya yang akan ditentukan kekurangan atau kelebihan penggunaannya. Biasanya dilambangkan dengan $b_{i}$ dimana $i=1,2, \ldots m$

3. Variabel simpangan/ Deviational variables: variabel-variabel yang menunjukkan kemungkinan penyimpangan dari suatu nilai-nilai RHS.

4. Fungsi kendala: suatu tujuan yang diekspresikan dalam persamaan matematik dengan memasukkan variabel simpangan. 
5. Tujuan/ goal (Z): keinginan untuk meminimumkan angka penyimpangan dari suatu nilai RHS pada suatu kendala tujuan tertentu.

6. Koefisien teknologi : Koefisien teknologi (technology coefficient) merupakan nilai-nilai numerik yang dilambangkan dengan $a_{i j}$ yang akan dikombinasikan dengan variabel keputusan dimana akan menunjukkan penggunaan terhadap pemenuhan nilai kanan.

7. Faktor prioritas/ Preemptive priority factor $\left(P_{k}\right)$ : suatu system urutan yang memungkinkan tujuantujuan disusun secara ordinal dalam model goal programming yang menempatkan tujuan dalam susunan dengan hubungan $P_{1}$ lebih penting dari $P_{2}$ dan $P_{2}$ lebih penting dari $P_{3}$.

8. Bobot/ Differential weight $\left(W_{k i}\right)$ : ukuran matematik yang diekspresikan dengan angka kardinal dan digunakan untuk membedakan variabel simpangan didalam suatu tingkat prioritas.

Setiap model goal programming terdiri dari tiga fungsi tujuan yaitu [6]:

$$
\text { Meminimumkan } Z=\sum_{i=1}^{m} d_{i}^{-}+d_{i}^{+}
$$

Fungsi tujuan ini digunakan jika variabel simpangan dalam suatu masalah tidak dibedakan menurut prioritas atau bobot.

$$
\text { Meminimumkan } Z=\sum_{i=1}^{m} P_{k}\left(d_{i}^{-}+d_{i}^{+}\right)
$$

Fungsi tujuan ini digunakan dalam suatu masalah dengan urutan tujuan diperlukan tetapi variable simpangan didalam setiap tingkat prioritas memiliki kepentingan yang sama.

Meminimumkan $Z=\sum_{i=1}^{m} W_{k i} P_{k}\left(d_{i}^{-}+d_{i}^{+}\right) \quad$ (4)

Fungsi tujuan ini, tujuan-tujuan diurutkan dan variabel simpangan pada setiap tingkat prioritas dibedakan dengan menggunakan bobot yang berlainan.

\subsection{Preemptive Goal programming}

Preemptive goal programming adalah program tujuan dimana masing-masing tujuan memiliki urutan tingkat prioritas. Apabila terdapat tujuan yang berlainan dan tujuan-tujuan tersebut saling bertentangan maka dapat dimungkinkan untuk menentukan tujuan yang diutamakan atau diprioritaskan [3].

Dalam menerapkan metode ini, pembuat keputusan harus mengurutkan tujuan mereka dari yang paling penting (tujuan ke-1) hingga yang tidak terlalu penting (tujuan ke- $n$ ). Koefisien fungsi objektif untuk tujuan $i$ ialah $P_{i}$ dan diasumsikan [12]:

$$
P_{1} \gg P_{2} \gg P_{3} \gg \cdots \gg P_{n}
$$

Artinya yaitu bobot untuk tujuan 1 lebih besar daripada bobot untuk tujuan 2, bobot untuk tujuan 2 lebih besar dari bobot untuk tujuan 3, dan begitu seterusnya. Pendefinisian $P_{1}, P_{2}, \ldots, P_{n}$ memastikan bahwa pembuat keputusan pertama-tama mencoba memenuhi tujuan yang paling penting (tujuan 1). Selain itu, pembuat keputusan juga mencoba sebisa mungkin untuk memenuhi tujuan kedua dan seterusnya.

Pada formulasi $\min z=d_{1}^{-}+d_{2}^{-}+d_{3}^{-}$, fungsi tujuannya dapat diubah menjadi $P_{1} d_{1}^{-}+P_{2} d_{2}^{-}+P_{3} d_{3}^{-}$. Untuk menerapkan model goal programming dengan prioritas, fungsi tujuan harus dipisah menjadi $n$ komponen, dengan komponen ke- $i$ memuat tujuan ke- $i$. Hal ini dapat dinotasikan sebagai berikut [12]:

$Z_{i}=$ fungsi tujuan yang memuat tujuan ke $i$, dengan $i=$

$$
1,2, \ldots, n
$$

Dari fungsi tujuan $\min z=d_{1}^{-}+d_{2}^{-}+d_{3}^{-}$, fungsi tujuan dipisah menjadi tiga komponen, yaitu $Z_{1}=P_{1} d_{1}^{-}, Z_{2}=$
$P_{2} d_{2}^{-}$, dan $Z_{3}=P_{3} d_{3}^{-}$dengan kendala yang sama seperti sebelumnya dan menambahkan kendala $d_{1}^{-}=\left(d_{1}^{-}\right)^{*}$ pada formulasi dengan fungsi tujuan $Z_{2}$ serta menambahkan kendala $d_{1}^{-}=\left(d_{1}^{-}\right)^{*}$ dan $d_{2}^{-}=\left(d_{2}^{-}\right)^{*}$ pada formulasi dengan tujuan $Z_{3}$ dengan $\left(d_{1}^{-}\right)^{*}$ dan $\left(d_{2}^{-}\right)^{*}$ merupakan nilai variabel deviasi yang diperoleh dari iterasi sebelumnya.

\section{METODE PENELITIAN}

\subsection{Waktu dan Tempat Penelitian}

Penelitian ini dilaksanakan pada bulan Oktober 2019 sampai Februari 2020. Pengambilan data dilakukan di Perusahaan Daerah Air Minum (PDAM) Kabupaten Bolaang Mongondow yang terletak di Jalan Arif Rahman Hakim No. 97 Kotamobagu dan pengolahan data dilakukan di Laboratorium Komputer Jurusan Matematika FMIPA Unsrat.

\subsection{Data Penelitian}

Penelitian ini menggunakan data sekunder yang diperoleh dari PDAM Kabupaten Bolaang Mongondow, data yang diambil berupa data kuantitatif yaitu:

1. Jumlah pelanggan berdasarkan jenis pelanggan unit Modayag dan unit Kotabunan bulan Januari 2018 sampai September 2019.

2. Volume penggunaan air bersih berdasarkan jenis pelanggan unit Modayag dan unit Kotabunan bulan Januari 2018 sampai September 2019.

3. Harga penjualan air bersih berdasarkan jenis pelanggan $\left(R p / m^{3}\right)$

4. Kapasitas produksi air bersih unit Modayag dan unit Kotabunan $\left(\mathrm{m}^{3}\right)$

\subsection{Langkah-Langkah Penelitian}

1. Pengumpulan data diambil dari Perusahaan Daerah Air Minum (PDAM) Kabupaten Bolaang Mongondow yang terletak di Jalan Arif Rahman Hakim No. 97 Kotamobagu

2. Menentukan rata-rata penggunaan air bersih berdasarkan jenis pelanggan.

3. Menentukan produksi minimal air bersih berdasarkan jenis pelanggan.

4. Melakukan prediksi jumlah pelanggan berdasarkan jenis pelanggan untuk periode Februari 2020.

5. Menentukan tingkat permintaan air bersih berdasarkan jenis pelanggan untuk periode Februari 2020.

6. Menentukan total pendapatan hasil penjualan air bersih bulan Februari 2020 berdasarkan tingkat permintaan air bersih dan tarif penjualan air bersih.

7. Pembentukan model preemptive goal programming dan diselesaikan dengan menggunakan salah satu software program linear.

8. Menganalisis output yang ditampilkan dan membuat kesimpulan berdasarkan hasil yang diperoleh

\section{HASIL DAN PEMBAHASAN}

\subsection{Rata-Rata Penggunaan Air Bersih Berdasarkan Jenis Pelanggan}

Data rata-rata penggunaan air bersih berdasarkan jenis pelanggan dapat dilihat pada tabel 1. 
Tabel 1. Rata-Rata Penggunaan Air Bersih

\begin{tabular}{|c|c|c|}
\hline \multirow{2}{*}{ Jenis Pelanggan } & \multicolumn{2}{|c|}{ Unit } \\
\hline & Modayag & Kotabunan \\
\hline Hidran Umum & 13,333 & 16,79 \\
\hline Tempat Ibadah & 37,043 & 66,195 \\
\hline Sekolah Negeri & 47,604 & 59,333 \\
\hline $\begin{array}{l}\text { Rumah Sakit } \\
\text { Pemerintah }\end{array}$ & 85,941 & 193,214 \\
\hline $\begin{array}{l}\text { Instansi Pemerintah } \\
\text { tingkat Kecamatan }\end{array}$ & 32,408 & 27,773 \\
\hline $\begin{array}{l}\text { Rumah selain RSS dan } \\
\text { Mewah }\end{array}$ & 15,831 & 21,127 \\
\hline Niaga Kecil & 31,682 & 35,321 \\
\hline $\begin{array}{l}\text { Instansi Pemerintah } \\
\text { Tingkat Kabupaten }\end{array}$ & 58,948 & 82,427 \\
\hline Rumah Mewah & 19,116 & 23,511 \\
\hline $\begin{array}{l}\text { Kamar Mandi/ WC } \\
\text { Umum }\end{array}$ & 25,51 & \\
\hline $\begin{array}{l}\text { Rumah Sangat } \\
\text { Sederhana (RSS) }\end{array}$ & 8,81 & \\
\hline Niaga Besar & 30,762 & \\
\hline Kelompok Khusus & 42,556 & \\
\hline
\end{tabular}

\subsection{Prediksi Jumlah Pelanggan Bulan Februari 2020}

Untuk menentukan target tingkat permintaan pelanggan maka terlebih dahulu harus diprediksi jumlah pelanggan berdasarkan jenis pelanggan untuk bulan Februari 2020 dengan menggunakan model trend linear. Hasil prediksi jumlah pelanggan unit Modayag dan Kotabunan dengan menggunakan model trend linear terdapat pada tabel 2.

Tabel 2. Prediksi Jumlah Pelanggan Bulan Februari 2020

\begin{tabular}{|c|c|c|}
\hline \multirow{2}{*}{ Jenis Pelanggan } & \multicolumn{2}{|c|}{ Unit } \\
\hline & Modayag & Kotabunan \\
\hline Hidran Umum & $\mathrm{O}$ & $\mathrm{O}$ \\
\hline Tempat Ibadah & 16 & 5 \\
\hline Sekolah Negeri & 16 & 2 \\
\hline $\begin{array}{l}\text { Rumah Sakit } \\
\text { Pemerintah }\end{array}$ & 2 & 1 \\
\hline $\begin{array}{l}\text { Instansi Pemerintah } \\
\text { tingkat Kecamatan }\end{array}$ & 6 & 1 \\
\hline $\begin{array}{l}\text { Rumah selain RSS dan } \\
\text { Mewah }\end{array}$ & 907 & 269 \\
\hline Niaga Kecil & 4 & 18 \\
\hline $\begin{array}{l}\text { Instansi Pemerintah } \\
\text { Tingkat Kabupaten }\end{array}$ & 3 & 4 \\
\hline Rumah Mewah & 9 & 13 \\
\hline $\begin{array}{l}\text { Kamar Mandi/ WC } \\
\text { Umum }\end{array}$ & 1 & \\
\hline $\begin{array}{l}\text { Rumah sangat } \\
\text { sederhana (RSS) }\end{array}$ & $\mathrm{O}$ & \\
\hline Niaga Besar & 1 & \\
\hline Kelompok Khusus & 5 & \\
\hline
\end{tabular}

\subsection{Tingkat Permintaan Air Bersih Berdasarkan Jenis Pelanggan Bulan Februari 2020}

Tingkat permintaan air bersih untuk bulan Februari 2020 dapat ditentukan dengan mengalikan data hasil prediksi jumlah pelanggan bulan Februari 2020 (Tabel 2) dengan data rata-rata penggunaan air bersih berdasarkan jenis pelanggan (Tabel 1). Tingkat permintaan air bersih untuk unit Modayag dan Kotabunan pada bulan Februari 2020 dapat dilihat pada tabel 3 .

Tabel 3. Tingkat Permintaan Air Bersih Bulan Februari 2020

\begin{tabular}{|c|c|c|}
\hline \multirow{2}{*}{ Jenis Pelanggan } & \multicolumn{2}{|c|}{ Unit } \\
\hline & Modayag & Kotabunan \\
\hline Hidran Umum & $\mathrm{O}$ & $\mathrm{O}$ \\
\hline Tempat Ibadah & 592,688 & 330,975 \\
\hline Sekolah Negeri & 761,664 & 118,66 \\
\hline $\begin{array}{l}\text { Rumah Sakit } \\
\text { Pemerintah }\end{array}$ & 171,882 & 193,214 \\
\hline $\begin{array}{l}\text { Instansi Pemerintah } \\
\text { tingkat Kecamatan }\end{array}$ & 194,448 & 27,773 \\
\hline $\begin{array}{l}\text { Rumah selain RSS dan } \\
\text { Mewah }\end{array}$ & 14358,72 & 5683,163 \\
\hline Niaga Kecil & 126,728 & 635,778 \\
\hline $\begin{array}{l}\text { Instansi Pemerintah } \\
\text { Tingkat Kabupaten }\end{array}$ & 176,844 & 329,708 \\
\hline Rumah Mewah & 172,044 & 305,643 \\
\hline $\begin{array}{l}\text { Kamar Mandi/ WC } \\
\text { Umum }\end{array}$ & 25,51 & \\
\hline $\begin{array}{l}\text { Rumah Sangat } \\
\text { sederhana (RSS) }\end{array}$ & 0 & \\
\hline Niaga Besar & 30,762 & \\
\hline Kelompok Khusus & 212,78 & \\
\hline
\end{tabular}

\subsection{Pendapatan Hasil Penjualan Air Bersih Bulan Februari 2020}

Total pendapatan unit Modayag dan unit Kotabunan bulan Februari 2020 yang disajikan pada tabel 4

Tabel 4. Pendapatan Hasil Penjualan Air Bersih Bulan Februari 2020

\begin{tabular}{|c|c|}
\hline Unit & Pendapatan (Rp) \\
\hline Modayag & 120291446 \\
\hline Kotabunan & 55192006 \\
\hline
\end{tabular}

\subsection{Produksi Minimal Air Bersih Berdasarkan Jenis Pelanggan}

Data produksi minimal air bersih unit Modayag dan unit Kotabunan disajikan pada tabel 5 .

Tabel 5. Produksi Minimal Air Bersih

\begin{tabular}{|l|c|c|}
\hline \multirow{2}{*}{ Jenis Pelanggan } & \multicolumn{2}{|c|}{ Unit } \\
\cline { 2 - 3 } & Modayag & Kotabunan \\
\hline Tempat Ibadah & 127 & 222 \\
\hline Sekolah Negeri & 136 & 20 \\
\hline $\begin{array}{l}\text { Rumah Sakit } \\
\text { Pemerintah }\end{array}$ & 185 & 19 \\
\hline $\begin{array}{l}\text { Instansi Pemerintah } \\
\text { tingkat Kecamatan }\end{array}$ & 39 & 7 \\
\hline $\begin{array}{l}\text { Rumah selain RSS dan } \\
\text { Mewah }\end{array}$ & 6278,65 & 4503,04 \\
\hline Niaga Kecil & 18 & 393,33 \\
\hline $\begin{array}{l}\text { Instansi Pemerintah } \\
\text { Tingkat Kabupaten }\end{array}$ & 157 & 97 \\
\hline Rumah Mewah & 105 & 274 \\
\hline $\begin{array}{l}\text { Kamar Mandi/ WC } \\
\text { Umum }\end{array}$ & 19,1 & \multicolumn{1}{|c|}{} \\
\hline Niaga Besar & 6 & \multicolumn{1}{|c|}{} \\
\hline Kelompok Khusus & 60 &
\end{tabular}

\subsection{Variabel Keputusan}


Lita S. Kawulusan, Altien J. Rindengan, Yohanes A. R. Langi

d'Cartesian : Jurnal Matematika dan Aplikasi, Vol. 9, No. 2 (September 2020): 120-125

Variabel keputusan unit Modayag dan unit Kotabunan dapat dilihat pada tabel 6 dan tabel 7 .

Tabel 6. Variabel Keputusan Unit Modayag

\begin{tabular}{|c|l|}
\hline $\begin{array}{c}\text { Variabel } \\
\text { Keputusan }\end{array}$ & \multicolumn{1}{c|}{ Keterangan } \\
\hline$x_{A 1}$ & $\begin{array}{l}\text { Jumlah produksi air bersih jenis } \\
\text { pelanggan kamar mandi/ wc umum }\end{array}$ \\
\hline$x_{A 2}$ & $\begin{array}{l}\text { Jumlah produksi air bersih jenis } \\
\text { pelanggan tempat ibadah }\end{array}$ \\
\hline$x_{A 3}$ & $\begin{array}{l}\text { Jumlah produksi air bersih jenis } \\
\text { pelanggan sekolah negeri }\end{array}$ \\
\hline$x_{A 4}$ & $\begin{array}{l}\text { Jumlah produksi air bersih jenis } \\
\text { pelanggan rumah sakit pemerintah }\end{array}$ \\
\hline$x_{A 5}$ & $\begin{array}{l}\text { Jumlah produksi air bersih jenis } \\
\text { pelanggan instansi pemerintah tingkat } \\
\text { kecamatan }\end{array}$ \\
\hline$x_{A 6}$ & $\begin{array}{l}\text { Jumlah produksi air bersih jenis } \\
\text { pelanggan rumah selain RSS dan mewah }\end{array}$ \\
\hline$x_{A 7}$ & $\begin{array}{l}\text { Jumlah produksi air bersih jenis } \\
\text { pelanggan niaga kecil }\end{array}$ \\
\hline$x_{A 8}$ & $\begin{array}{l}\text { Jumlah produksi air bersih jenis } \\
\text { pelanggan instansi pemerintah tingkat } \\
\text { kabupaten }\end{array}$ \\
\hline$x_{A 9}$ & $\begin{array}{l}\text { Jumlah produksi air bersih jenis } \\
\text { pelanggan rumah mewah }\end{array}$ \\
\hline$x_{A 10}$ & $\begin{array}{l}\text { Jumlah produksi air bersih jenis } \\
\text { pelanggan niaga besar }\end{array}$ \\
\hline$x_{A 11}$ & $\begin{array}{l}\text { Jumlah produksi air bersih jenis } \\
\text { pelanggan kelompok khusus }\end{array}$ \\
\hline
\end{tabular}

Tabel 7. Variabel Keputusan Unit Kotabunan

\begin{tabular}{|c|l|}
\hline $\begin{array}{c}\text { Variabel } \\
\text { Keputusan }\end{array}$ & \multicolumn{1}{c|}{ Keterangan } \\
\hline$x_{B 1}$ & $\begin{array}{l}\text { Jumlah produksi air bersih jenis } \\
\text { pelanggan tempat ibadah }\end{array}$ \\
\hline$x_{B 2}$ & $\begin{array}{l}\text { Jumlah produksi air bersih jenis } \\
\text { pelanggan sekolah negeri }\end{array}$ \\
\hline$x_{B 3}$ & $\begin{array}{l}\text { Jumlah produksi air bersih jenis } \\
\text { pelanggan rumah sakit pemerintah }\end{array}$ \\
\hline$x_{B 4}$ & $\begin{array}{l}\text { Jumlah produksi air bersih jenis } \\
\text { pelanggan instansi pemerintah } \\
\text { tingkat kecamatan }\end{array}$ \\
\hline$x_{B 5}$ & $\begin{array}{l}\text { Jumlah produksi air bersih jenis } \\
\text { pelanggan rumah selain RSS dan } \\
\text { mewah }\end{array}$ \\
\hline$x_{B 6}$ & $\begin{array}{l}\text { Jumlah produksi air bersih jenis } \\
\text { pelanggan niaga kecil }\end{array}$ \\
\hline$x_{B 7}$ & $\begin{array}{l}\text { Jumlah produksi air bersih jenis } \\
\text { pelanggan instansi pemerintah } \\
\text { tingkat kabupaten }\end{array}$ \\
\hline$x_{B 8}$ & $\begin{array}{l}\text { Jumlah produksi air bersih jenis } \\
\text { pelanggan rumah mewah }\end{array}$ \\
\hline
\end{tabular}

\subsection{Formulasi Model}

- Tujuan

$\operatorname{Min} Z=P_{1}\left(\sum_{q=1}^{19} d_{q m}+d_{q p}\right)+$

$P_{2}\left(\sum_{r=20}^{21} d_{r m}+d_{r p}\right)+P_{3}\left(\sum_{s=22}^{23} d_{s m}+d_{s p}\right)+$

$P_{4}\left(\sum_{t=24}^{42} d_{t m}+d_{t p}\right)$

- Kendala tingkat permintaan

$x_{A 1}+d_{1 m}-d_{1 p}=25,51$

$x_{A 2}+d_{2 m}-d_{2 p}=592,688$

$x_{A 3}+d_{3 m}-d_{3 p}=761,664$
$x_{A 4}+d_{4 m}-d_{4 p}=171,882$

$x_{A 5}+d_{5 m}-d_{5 p}=194,448$

$x_{A 6}+d_{6 m}-d_{6 p}=14358,72$

$x_{A 7}+d_{7 m}-d_{7 p}=126,728$

$x_{A 8}+d_{8 m}-d_{8 p}=176,844$

$x_{A 9}+d_{9 m}-d_{9 p}=172,044$

$x_{A 10}+d_{10 m}-d_{10 p}=30,762$

$x_{A 11}+d_{11 m}-d_{11 p}=212,78$

$x_{B 1}+d_{12 m}-d_{12 p}=330,975$

$x_{B 2}+d_{13 m}-d_{13 p}=118,666$

$x_{B 3}+d_{14 m}-d_{14 p}=193,214$

$x_{B 4}+d_{15 m}-d_{15 p}=27,773$

$x_{B 5}+d_{16 m}-d_{16 p}=5683,163$

$x_{B 6}+d_{17 m}-d_{17 p}=635,778$

$x_{B 7}+d_{18 m}-d_{18 p}=329,708$

$x_{B 8}+d_{19 m}-d_{19 p}=305,643$

- Kendala pendapatan

$3266 x_{A 1}+3266 x_{A 2}+3833 x_{A 3}+3833 x_{A 4}+$

$3833 x_{A 5}+7333 x_{A 6}+9000 x_{A 7}+9000 x_{A 8}+$ $8000 x_{A 9}+9500 x_{A 10}+20000 x_{A 11}+d_{20 m}-d_{20 p}=$ 120291446

$3266 x_{B 1}+3833 x_{B 2}+3833 x_{B 3}+3833 x_{B 4}+$ $7333 x_{B 5}+9000 x_{B 6}+9000 x_{B 7}+8000 x_{B 8}+d_{21 m}-$ $d_{21 p}=55192006$

- Kendala kapasitas produksi

$x_{A 1}+x_{A 2}+x_{A 3}+x_{A 4}+x_{A 5}+x_{A 6}+x_{A 7}+x_{A 8}+$ $x_{A 9}+x_{A 10}+x_{A 11}+d_{22 m}-d_{22 p}=29808$

$x_{B 1}+x_{B 2}+x_{B 3}+x_{B 4}+x_{B 5}+x_{B 6}+x_{B 7}+x_{B 8}+$ $d_{23 m}-d_{23 p}=12960$

- Kendala produksi minimal air bersih

$x_{A 1}+d_{24 m}-d_{24 p}=19,9$

$x_{A 2}+d_{25 m}-d_{25 p}=127$

$x_{A 3}+d_{26 m}-d_{26 p}=136$

$x_{A 4}+d_{27 m}-d_{27 p}=185$

$x_{A 5}+d_{28 m}-d_{28 p}=39$

$x_{A 6}+d_{29 m}-d_{29 p}=6278,65$

$x_{A 7}+d_{30 m}-d_{30 p}=18$

$x_{A 8}+d_{31 m}-d_{31 p}=157$

$x_{A 9}+d_{32 m}-d_{32 p}=105$

$x_{A 10}+d_{33 m}-d_{33 p}=6$

$x_{A 11}+d_{34 m}-d_{34 p}=60$

$x_{B 1}+d_{35 m}-d_{35 p}=222$

$x_{B 2}+d_{36 m}-d_{36 p}=20$

$x_{B 3}+d_{37 m}-d_{37 p}=19$

$x_{B 4}+d_{38 m}-d_{38 p}=7$

$x_{B 5}+d_{39 m}-d_{39 p}=4503,04$

$x_{B 6}+d_{40 m}-d_{40 p}=393,33$

$x_{B 7}+d_{41 m}-d_{41 p}=97$

$x_{B 8}+d_{42 m}-d_{42 p}=274$

\subsection{Solusi Optimal Model Preemptive Goal programming}

Tabel 8. Solusi Optimal Jumlah Produksi Air Bersih

\begin{tabular}{|c|c|c|c|}
\hline $\begin{array}{c}\text { Variabel } \\
\text { Keputusan }\end{array}$ & $\begin{array}{c}\text { Jumlah } \\
\text { Produksi } \\
\text { Air }\left(\boldsymbol{m}^{\mathbf{3}}\right)\end{array}$ & $\begin{array}{c}\text { Variabel } \\
\text { Keputusan }\end{array}$ & $\begin{array}{c}\text { Jumlah } \\
\text { Produksi } \\
\text { Air }\left(\boldsymbol{m}^{\mathbf{3}}\right)\end{array}$ \\
\hline$x_{A 1}$ & 25,51 & $x_{B 1}$ & 330,975 \\
\hline$x_{A 2}$ & 592,688 & $x_{B 2}$ & 118,666 \\
\hline$x_{A 3}$ & 761,664 & $x_{B 3}$ & 193,214 \\
\hline$x_{A 4}$ & 171,882 & $x_{B 4}$ & 27,773 \\
\hline
\end{tabular}




\begin{tabular}{|c|c|c|c|}
\hline$x_{A 5}$ & 194,448 & $x_{B 5}$ & 5683,163 \\
\hline$x_{A 6}$ & 14358,72 & $x_{B 6}$ & 635,778 \\
\hline$x_{A 7}$ & 126,728 & $x_{B 7}$ & 329,708 \\
\hline$x_{A 8}$ & 176,844 & $x_{B 8}$ & 305,643 \\
\hline$x_{A 9}$ & 172,044 & Total & $\mathbf{7 6 2 4 , 9 2}$ \\
\hline$x_{A 10}$ & 30,762 & \multicolumn{3}{|c}{} \\
\cline { 1 - 2 }$x_{A 11}$ & 212,78 & \multicolumn{2}{|c}{} \\
\cline { 1 - 2 } Total & $\mathbf{1 6 8 2 4 , 0 7}$ & &
\end{tabular}

Dengan menggunakan model preemptive goal programming maka prioritas pertama yaitu memenuhi permintaan air bersih berdasarkan jenis pelanggan pada unit Modayag dan unit Kotabunan dapat terpenuhi, hal ini karena semua variabel simpangan positif dan variabel simpangan negatif pada kendala tingkat permintaan air bersih bernilai o. Untuk prioritas kedua yaitu memaksimalkan pendapatan penjualan air bersih juga dapat terpenuhi karena variabel simpangan negatif kendala pendapatan pada unit Modayag dan unit Kotabunan bernilai o sebaliknya variable simpangan positif kendala pendapatan untuk unit Modayag bernilai 22,43 sehingga total pendapatan yang akan diperoleh unit Modayag sebesar Rp.120.291.468 dan variable simpangan positif kendala pendapatan untuk unit Kotabunan bernilai o,578 sehingga total pendapat yang diperoleh unit Kotabunan sebesar Rp.55.192.006. Adapun untuk prioritas ketiga yaitu memproduksi air bersih yang tidak melebihi kapasitas produksi dapat terpenuhi karena jumlah produksi air bersih pada unit Modayag dan unit Kotabunan tidak melebihi kapasitas produksi yang sudah ditetapkan pada kendala tujuan. Untuk prioritas keempat yaitu memproduksi air bersih yang melebihi produksi minimal air bersih, terdapat satu variabel keputusan yang memiliki nilai solusi optimal kurang dari produksi minimal air bersih yang telah ditetapkan pada kendala tujuan, variabel keputusan tersebut yaitu $x_{A 4}$. Selain variabel keputusan tersebut, nilai variabel keputusan yang lainnya telah melebihi produksi minimal air bersih yang telah ditetapkan pada kendala tujuan.

\section{Penutup \\ 5.1. Kesimpulan}

Berdasarkan hasil yang diperoleh dengan menggunakan metode preemptive goal programming maka jumlah produksi air bersih bulan Februari 2020 untuk unit Modayag yaitu sebesar 16824,07 $\mathrm{m}^{3}$ dan jumlah produksi air bersih untuk unit Kotabunan sebesar 7624,92 $\mathrm{m}^{3}$ dengan target pendapatan yang terpenuhi untuk unit Modayag sebesar Rp.120.291.468 dan untuk unit Kotabunan sebesar Rp.55.192.006

\section{REFERENSI}

[1] Aprilian, T. 2016. Persepsi Masyarakat Terhadap Kualitas Pelayanan Pengaduan Perusahaan Daerah Air Minum (Pdam) di Desa Sukaraja Kecamatan Gedong Tataan Kabupaten Pesawaran [Skripsi]. Universitas Lampung, Bandar Lampung.

[2] Dimyati, T.T,. dan A. Dimyati. 2009. Operations Research Model-Model Pengambilan Keputusan. Sinar Baru Algensindo, Bandung.

[3] Hillier, F.S., dan G.J. Lieberman. 1994. Pengantar Riset Operasi. Edisi ke-5. Erlangga, Jakarta.

[4] Nelwan, C., J.S. Kekenusa dan Y.A.R. Langi. 2013. Optimasi Pendistribusi Air dengan Menggunakan Metode Least Cost dan Metode Modified
Distribution. Jurnal Ilmiah Sains. 13(1):45-51.

[5] Raden, L., Y.A.R. Langi dan T. Manurung. 2013 Optimasi Pendistribusian Raskin dengan Menggunakan Goal Programming. Jurnal MIPA Unsrat Online 2(1):12-16.

[6] Rangkuti, A. 2013. 7 Model Riset Operasi dan Aplikasinya. Brilian Internasional, Surabaya.

[7] Santoso. 2001. Pengantar Ilmu Lingkungan. FMIPA UNNES, Semarang.

[8] Santoso, P.B., dan M. Hamdani. 2007. Statistika Deskriptif dalam Bidang Ekonomi dan Niaga. Erlangga, Jakarta.

[9] Siswanto. 2007. Operations Research. Edisi ke-1. Erlangga, Jakarta.

[10] Sualang, M., J.S. Kekenusa dan N. Nainggolan. 2018. Optimasi Produksi Air Bersih Pelanggan PT. Air Manado Menggunakan Metode Goal Programming. Jurnal De Cartesian 7(1):29-34.

[11] Sutrisno. 2004. Teknologi Penyediaan Air Bersih. Rineka Cipta, Jakarta.

[12] Winston, W.L. 2004. Operations Research Applications and Algorithms $4^{\text {th }}$ ed. Duxbury, New York.

Lita S. Kawulusan (litakawulusan16@gmail.com)



Lahir di Kotamobagu, Sulawesi Utara pada tanggal 16 Maret 1997. Menempuh pendidikan tinggi Jurusan Matematika, FMIPA, Universitas Sam Ratulangi Manado. Tahun 2020 adalah tahun terakhir ia menempuh studi. Makalah ini merupakan hasil penelitian skripsinya yang dipublikasikan.

\section{Altien J. Rindengan (altien@unsrat.ac.id)}

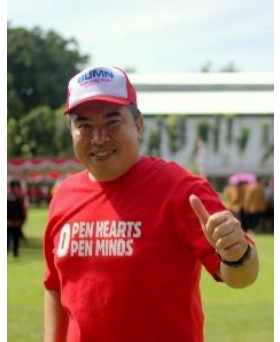

Lahir pada tanggal 27 April 1974. Pada tahun 1999 memperoleh gelar Sarjana Sains (S.Si) di Departemen Matematika, Fakultas Matematika dan Ilmu Pengetahuan Alam, Institut Pertanian Bogor. Gelar Magister Ilmu Komputer diperoleh dari Institut Pertanian Bogor pada tahun 2012. Menjadi dosen di Jurusan Matematika, FMIPA, Universitas Sam Ratulangi Manado sejak tahun 2001 sampai sekarang.

Yohanes A. R. Langi (yarlangi@gmail.com)

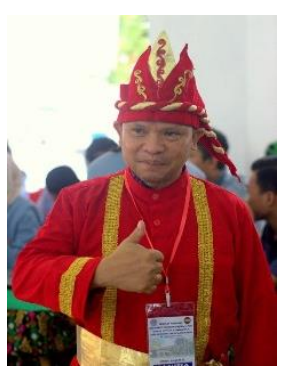

Lahir di Jakarta pada tanggal 13 Juni 1970. Pada tahun 1994, memperoleh gelar Sarjana Sains (S.Si) di Universitas Kristen Indonesia Tomohon. Gelar Magister Sains (M.Si) diperoleh dari Institut Pertanian Bogor (IPB) pada tahun 2007. Ia bekerja di UNSRAT di Program Studi Matematika sebagai pengajar akademik tetap UNSRAT. 